\title{
溶融 $\mathrm{MgCl}_{2}-\mathrm{CsCl} 2$ 成分系の密度およびモル体積
}

$$
\begin{array}{lllll}
\text { 江島 辰 } & \text { 彦* 佐 藤 } & \text { 讓* } \\
\text { 安 藤 } & \text { 明 男** 浅 川 輝 彦*** }
\end{array}
$$

J.Japan Inst. Metals. Vol.45, No.4(1981),pp.368 373

Density and Molar Volume of $\mathrm{MgCl}_{2}-\mathrm{CsCl}$ Binary Melt

Tatsuhiko Ejima*, Yuzuru Sato*, Akio Ando** and Teruliko Asakawa***

\begin{abstract}
Density of $\mathrm{MgCl}_{2}$-CsCl binary melt has been measured over the temperature range of liquidus to about $1200 \mathrm{~K}$ by means of the manometric method using a transparent furnace and $\mathrm{U}$ type manometer. The results obtained are summarized as follows:

The density increases monotonously with increasing $\mathrm{CsCl}$ content. The expansion coefficient of pure $\mathrm{MgCl}_{2}$ is significantly small, but that of the binary melt increases to about $30 \mathrm{~mol} \% \mathrm{CsCl}$. The molar volume deviates positively from the additivity over the whole range of composition, and its deviation shows a maximum at about $65 \mathrm{~mol} \% \mathrm{CsCl}$ which corresponds nearly to the stoichiometric composition of the compound $\mathrm{Cs}_{2} \mathrm{MgCl}_{4}$. In the binary melt, the partial molar volume of $\mathrm{MgCl}_{2}$ increases steeply with increasing $\mathrm{CsCl}$ content in the composition range of more than $50 \mathrm{~mol} \% \mathrm{CsCl}$, while that of $\mathrm{CsCl}$ exhibits a maximum at about $30 \mathrm{~mol} \% \mathrm{CsCl}$. The volumetric behavior of the melt was explained in terms of the model which describes the constitution of ionic species including the $\mathrm{MgCl}_{4}^{2-}$ complex anion in the melt.

The molar volume and expansion coefficient of each compound included in the melt were estimated by using the model of construction of the melt containing $\mathrm{MgCl}_{2}$ on the assumption of the additivity among the volumes of ionic species.
\end{abstract}

(Received December 23, 1980)

\section{I. 緒言}

$\mathrm{MgCl}_{2}$ はマグネシウム電解浴の主成分として用いられる 工業的炕重要な塩であるばかりでなく、アルカり金属塩化 物などとの溶融泥合物系の密度や電導度，表面張力などの

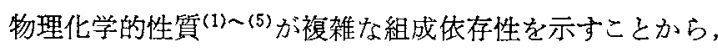
融体を構成するイオン種と物理化学的諸性貿々の関連やそ れらを左右する内子についての検討がなされている與味深 い物質である。このように複雑な組成低存性を示すのは $\mathrm{Mg}-\mathrm{Cl}$ 間の結合が共有結合的性質を有し，溶融 $\mathrm{MgCl}_{2}$ あ るいは混合溶融塩系において錯イオン形成傾向が強いため であると考えられている。

そこで本矿究では $\mathrm{MgCl}_{2}$-アルカリ金属塩化物 2 成分 系中，最子錯体形成傾向の強い $\mathrm{MgCl}_{2}-\mathrm{CsCl}_{2}$ 成分系の 密度を全組成範囲にわたり，液相線温度から $1200 \mathrm{~K}$ まで の温度範用で測定し，モル体積や膨張係数などを求めて融 体を構成するイオン種との関連において体積的举動を検討 することにした。
II. 実

験 易いので，試料を外部から完全に遮断することが可能か つ正確で測定精度の高いマノメータ法を用いて密度を測定 した，装置の構成㔚よび操作法は既報 ${ }^{(6)}$ 亿詳述したので省 略する. $\mathrm{MgCl}_{2}-\mathrm{CsCl}_{2}$ 成分系では $\mathrm{MgCl}_{2}$ と $\mathrm{CsCl}$ の密度 差が大であるため，透明石英製のU字型マノメータに装入 した試料の組成の不均一すなわらU字管下部ほど密度の大 きい $\mathrm{CsC1}$ の濃度が高くなる現象が起きやすい，そこで測 定にあたっては試料を溶融した後，水銀リザーバによって 試料をU字管内で繰り返し上下動させて擋找し，試料の組 成が均一になるよらに留意した。

$\mathrm{MgCl}_{2}$ は吸湿性が著しく，加水分解し易いために高純度 の烸水盐は入手し難い、また，真空加熱などよって水和 塩より結晶水を除去しようとしても酸化物などが生成する ため純粋な無水 $\mathrm{MgCl}_{2}$ を得ることができない，そこで本

* 東北大学工学部金属工学科(Department of Metallurgy, Faculty of Engineering, Tohoku University, Senđai)

** 東北大学大学院，現在：東京芝浦電気株式会社(Graduate School, Tohoku University, Sendai. Present address: Toshiba Corporation, Tokyo)

*** 東北大学工学部, 現在：アルプス電気株式会社(Faculty of Engineering, Tohoku University, Sendai. Present address : Alps Electric Co., Ltd., Tokyo) 
研究では複塩法拉よび塩化水素処理法を併用して照水 $\mathrm{MgCl}_{2}$ を得ることにした。すなわち特級試楽の $\mathrm{MgCl}_{2}$. $6 \mathrm{H}_{2} \mathrm{O}$ および $\mathrm{NH}_{4} \mathrm{Cl}$ を等モル量蒸溜水に溶解し，これを 蒸発・乾涸して $\mathrm{MgCl}_{2} \cdot \mathrm{NH}_{4} \mathrm{Cl} \cdot 3 \mathrm{H}_{2} \mathrm{O}$ なる水和複塩を作 る。この複塩を乾燥器中で一昼夜 $400 \mathrm{~K}$ に加熱して結唱水 の大部分を除去し，次に脱 $\mathrm{NH}_{4} \mathrm{Cl}$ 装置中に装入乙て真空 下約 $480 \mathrm{Kk}$ k $18 \sim 21.6 \mathrm{ks}(5 \sim 6 \mathrm{~h})$ 加熱乙て十分飞脱水す る.脱水が完了した後 Ar ガスを流しながら約 $700 \mathrm{~K} に$ 加熱して複塩分解を行い， $\mathrm{NH}_{4} \mathrm{Cl}$ を年華除去して無水 $\mathrm{MgCl}_{2}$ を得る。得られた無水 $\mathrm{MgCl}_{2}$ は灰白色で見掛け密 度の小さい極めて微細な粉末であるので溶融精製を行う。

無水粉末 $\mathrm{MgCl}_{2}$ を約 $600 \mathrm{~K}$ で真空加熱した後, 乾燥 $\mathrm{HCl}$ 雲囲気下で加熱溶融し，溶融試料中に乾燥 $\mathrm{HCl}$ ガスを吹 き込んで残存酸化物や微量水分学除去する. しかる後, 畭 燥 $\mathrm{Ar}$ を吹を込んで過鄱の $\mathrm{HCl}$ を放出させ真空下で凝固 させて無色透明の純粋な無水 $\mathrm{MgCl}_{2}$ の層状結晶を得た。

一方, $\mathrm{CsCl}$ については特級試薬を用い真空下約 $600 \mathrm{~K}$ で乾燥した後, 乾燥 $\mathrm{HCl}$ 雲囲気下で溶融する。この溶融 $\mathrm{CsCl}$ 中に乾燥 $\mathrm{HCl}$ 和よび乾燥 $\mathrm{Ar}$ を吹き込んで処理し, 真空下で凝固させて試料とした。

湘定終了後, 試料全量を蒸溜水に溶解 L, 所定の澧度に 希釈した後， Mg およびCsについてそれぞれ原子吸光分 析および炎光分析によって定量し組成を決定した。決定さ れた組成の誤差は $0.5 \mathrm{~mol} \%$ 以下であった。

\section{III. 実験 結 果}

測定された密度を各組成毎に温度に対しプロットして Fig.1 に图示し,さらにこれらの湘定值より密度を温度の 1

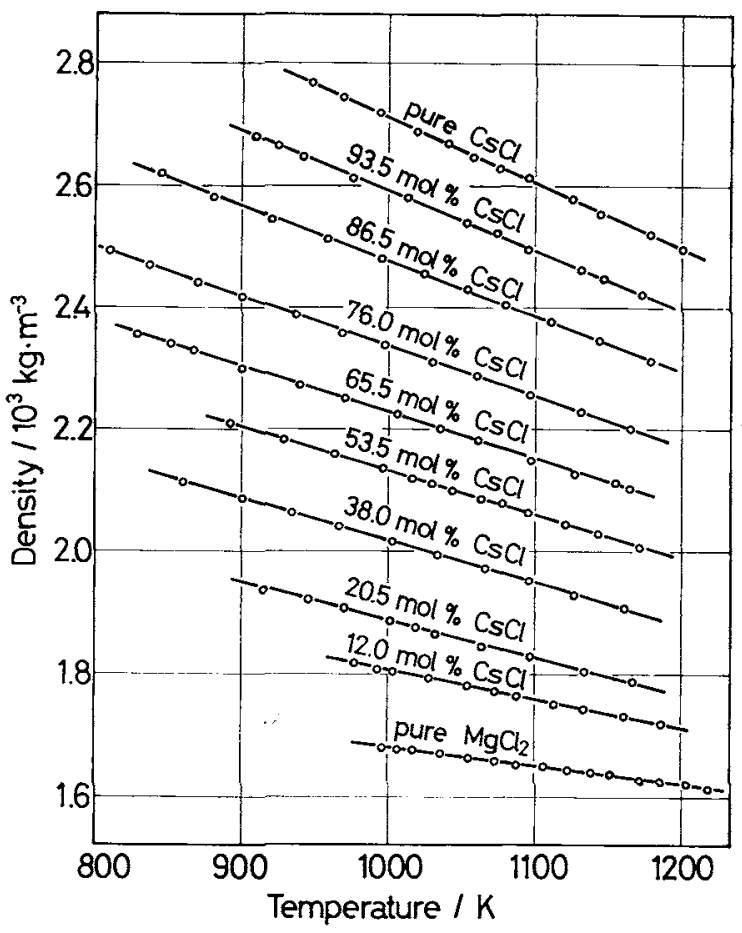

Fig.1 Densities of $\mathrm{MgCl}_{2}$-CsCl binary melts.
次式として各組成能に最小自乗法によって回掃した結果を Table 1 亿示した。充た回深式より求めた $1000 \mathrm{~K}, 1100 \mathrm{~K}$ および $1200 \mathrm{~K}$ に和斿る密度の組成依存性をFig.2 2 図示 した，図上り明らかなよらに $\mathrm{MgCl}_{2}-\mathrm{CsCl}$ 系の密度は $\mathrm{CsCl}$ 添加量の増加と共に単調に增加する。この場合，組 成に対する密度の增加率は $\mathrm{MgCl}_{2} お$ よ゙ $\mathrm{CSCl}$ 富側の組 成螌囲で大きな値を示すが 30〜70 mol\% $\mathrm{CsCl}$ の組成範囲 では比較的小さく，全体として逆 S 字型の特徴的な組成依 存性を示寸．さらに $\mathrm{MgCl}_{2}$ 富側に沶いて温度依存性がかな り小さいことも注目に值する。本 2 成分系の密度を組成拉 よび温度の関数として抱括的に表わすため既報 ${ }^{(6)}$ と同様に Table 1 亿示した係数を組成の 3 次式として近似し Table 2 に示した。これに基ついて計算した密度はほぼ $0.2 \%$ 以 内で実測值とよく一致した。

$\mathrm{MgCl}_{2}-\mathrm{CsCl} 2$ 成分系については全組成範围にわたって 密度を測定した報告がなく，わずかに CsCl $70 \mathrm{~mol} \%$ 付 近の組成についての测定が Grjotheim ら (1) とょってなざ

Table 1 Parameters of the density equation for $\mathrm{MgCl}_{2}-\mathrm{CsCl}$ binary melt.

\begin{tabular}{r|c|r|r}
\hline \multicolumn{3}{c}{$\rho=\left(a-b \cdot 10^{-4} \mathrm{~T}\right) \times 10^{3} \mathrm{~kg} \cdot \mathrm{m}^{-3}(T$ in $\mathrm{K})$} \\
\hline mol\%CsCl & $a$ & $b$ & std. dev. \\
\hline 0.0 & 1.9734 & 2.944 & 0.0014 \\
12.0 & 2.2727 & 4.674 & 0.0011 \\
20.5 & 2.4869 & 6.007 & 0.0015 \\
38.0 & 2.7084 & 6.917 & 0.0008 \\
53.5 & 2.8488 & 7.179 & 0.0009 \\
63.5 & 2.9801 & 7.540 & 0.0019 \\
76.0 & 3.1501 & 8.151 & 0.0016 \\
86.5 & 3.3742 & 8.990 & 0.0022 \\
93.5 & 3.5646 & 9.750 & 0.0017 \\
100.0 & 3.7701 & 10.611 & 0.0014 \\
\hline
\end{tabular}

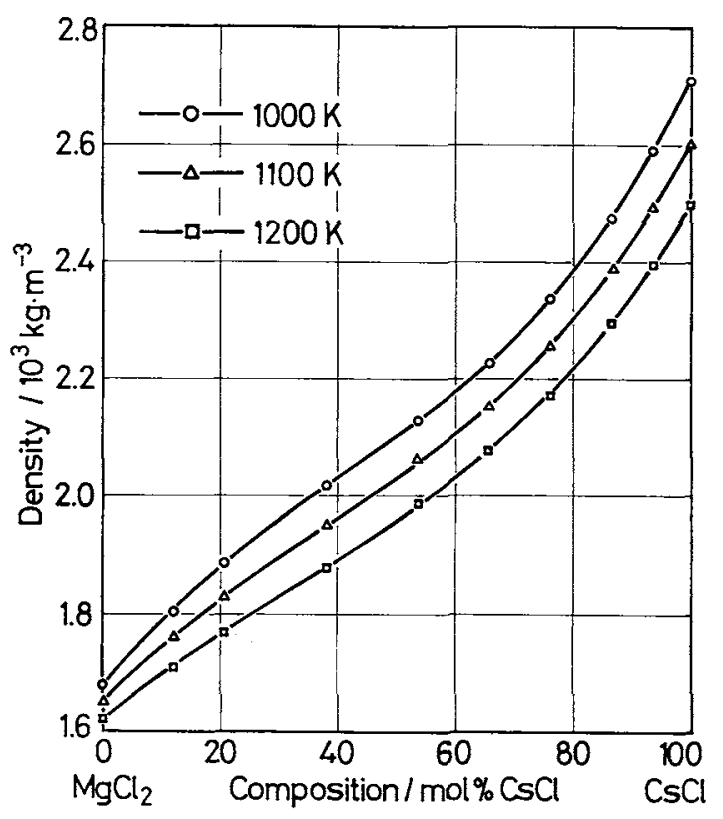

Fi.2 Density isotherms of $\mathrm{MgCl}_{2}-\mathrm{CsCl}$ binary melt. 
Table 2 Equation of the density for $\mathrm{MgCl}_{2}-\mathrm{CsCl}$ binary melt.

$$
\begin{aligned}
& \rho_{=}\left(\rho_{0}-\rho_{1} \cdot 10^{-4} \mathrm{~T}\right) \times 10^{3} \mathrm{~kg} \cdot \mathrm{m}^{-3} \\
& X=\mathrm{mol} \text { fraction of } \mathrm{CsCl} \\
& T \text { in } \mathrm{K}
\end{aligned}
$$

$\rho_{0}=1.967+3.279 X-4.813 X^{2}+3.344 X^{3}$

$\rho_{1}=2.907+20.19 X-33.92 X^{2}+21.51 X^{3}$

れているだけである、Grjotheim らの報告値は本研究結 果之比較的よい一致を示して拈り，なた純 $\mathrm{MgCl}_{2}$ および

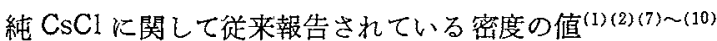
も本研究結果と概ね $0.5 \%$ 程度の範囲内で良く一致してい るが，全組成範囲について比較することはできない。

\section{IV. 考察}

溶融 $\mathrm{MgCl}_{2}-\mathrm{CsCl} 2$ 成分系の体積的举動を検討するため モル体積 $V_{M}$ を式（1）によって求めてみる。

$$
V_{\boldsymbol{M}}=\left(X_{\mathrm{MgCl}_{2}} W_{\mathrm{MgCl}_{2}}+X_{\mathrm{CsCl}} W_{\mathrm{CsCl}}\right)^{\rho}
$$

ここで $X$ および $W$ はそれぞれ， $\mathrm{MgCl}_{2}$ あるいは $\mathrm{CsCl}$ のモル分率就よ゙モル質量である，密度 $\rho$ の算出には
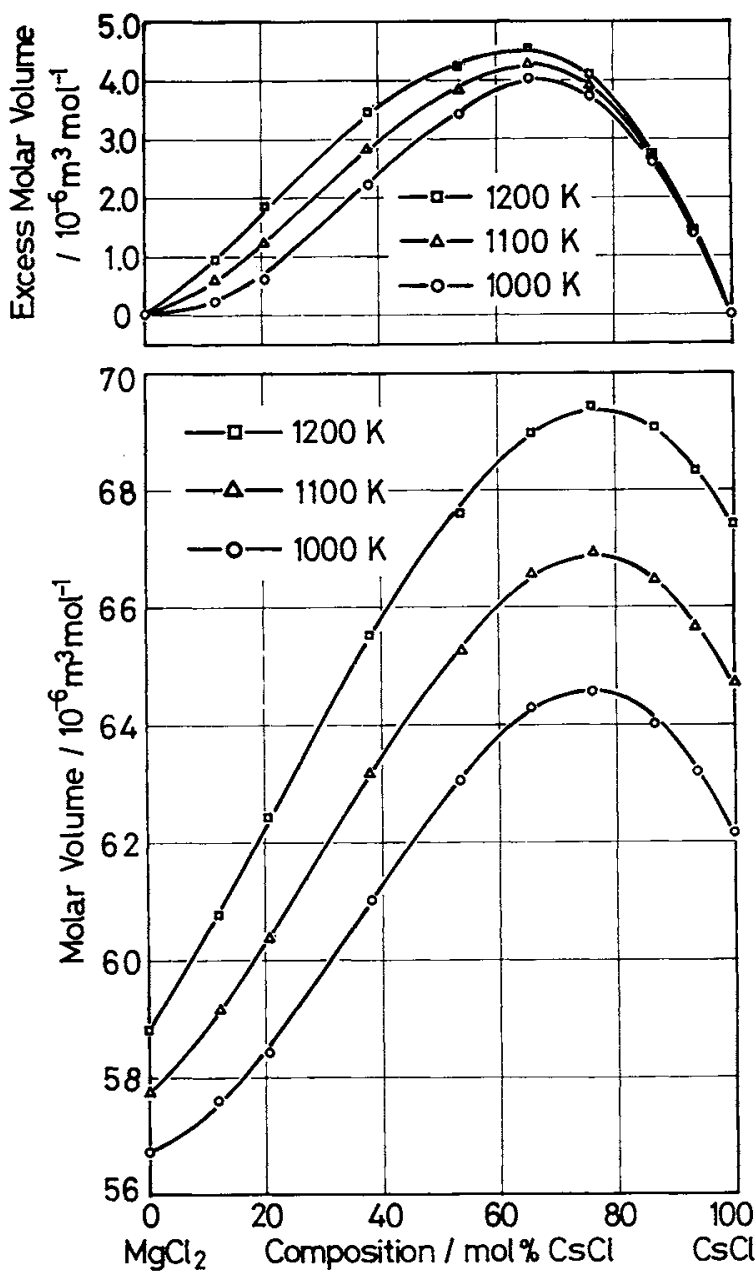

Fig.3 Molar volume and excess molar volume of $\mathrm{MgCl}_{2}-\mathrm{CsCl}$ binary melt.
Table 1 の値を用い $1000 \mathrm{~K}, 1100 \mathrm{~K}$ 抢よび $1200 \mathrm{~K} に$ に拈 るモル体積，ならびにモル体積の加成性よりの偏倚量であ る過剩モル体積を求めて Fig.3 に図示した。本 2 成分系 以外の $\mathrm{MgCl}_{2}$ とアルカリ金属塩化物の混合塩においては アルカリ金属塩化物富側で正の過剩モル体皘, $\mathrm{MgCl}_{2}$ 富側 で負の過剰モル体積を示すことが認められている。これら の系ではアルカリ金属イオンの寸法が大さくなるほど過剰 モル体積が正に增大する傾向を有するので， $\mathrm{MgCl}_{2}-\mathrm{CsCl}$ 2 成分系では負の過剰モル体積を示す組成範国は他の系に くらべ小さいことが予想される。然るにFig.3より明らか なよらにモル体積は最大值を有する組成低存性を示し，過 剩モル体積は予想のように全組成範团にわたって正の值を 示す，また過剰モル体積は温度の上昇に伴って若于増加す るが，いずれの温度に打いても CsCl 約 $65 \mathrm{~mol} \%$ すなわ ๖ $\mathrm{MgCl}_{2}: \mathrm{CsCl}=1: 2$ の化学量論組成の付近で最大值を 示す，最大值を示す組成より $\mathrm{MgCl}_{2}$ 富側では過剰モル体 積は温度に依存して増加するが $\mathrm{CsCl}$ 富側ではほとんど変 化しない，また膨張係数 $\alpha$ を式(2)により求め，1100 K に和ける値をFig.4にブロットした。

$$
\alpha=\frac{1}{V_{M}}\left(\frac{\partial V_{M}}{\partial T}\right)_{P}
$$

$\mathrm{MgCl}_{2}$ の膨張係数は $\mathrm{CsCl}$ のそれの約 $1 / 3$ で他の典型的な イオン性溶融塩のそれよりも非常に小さい。このように膨 張係数の小さな $\mathrm{MgCl}_{2}$ に CsCl を添加していくと $\mathrm{CsCl} 30$ $\mathrm{mol} \%$ 付近まで膨張 係数は急激に増加する。 それ以上の 組成ではほぼ一定の值を示すようになるがさらにCsC1の 添加量を增すと再び増加するようになる。

次に各成分の体積挙動を検討するために部分モル体積を 求めた. Table 2 に示した密度の関数を用いて $1000 \mathrm{~K}, 1100$ Kおよび $1200 \mathrm{~K} に$ 和ける $\mathrm{MgCl}_{2}$ 和るび CsClの部分モル体 積を求めFig.5に図示した。本たFig.5にはそれぞれの 部分モ儿体積の $1100 \mathrm{~K}$ に打ける膨張係数をむ併せて図示 した、 $\mathrm{MgCl}_{2}$ の部分モル体積は $\mathrm{CsCl}$ を添加すると最初は ほ活一定の值，あるいは若干减少する傾向を示すが CsCl

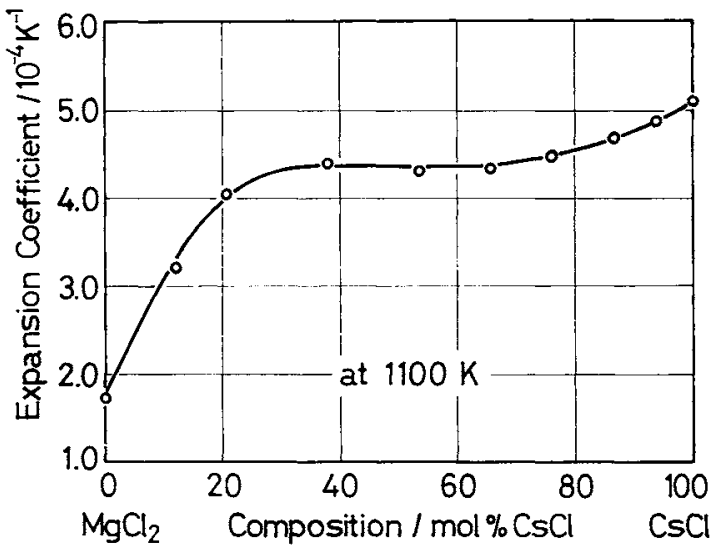

Fig.4 Expansion coefficient of $\mathrm{MgCl}_{2}-\mathrm{CsCl}$ binary melt at $1100 \mathrm{~K}$. 

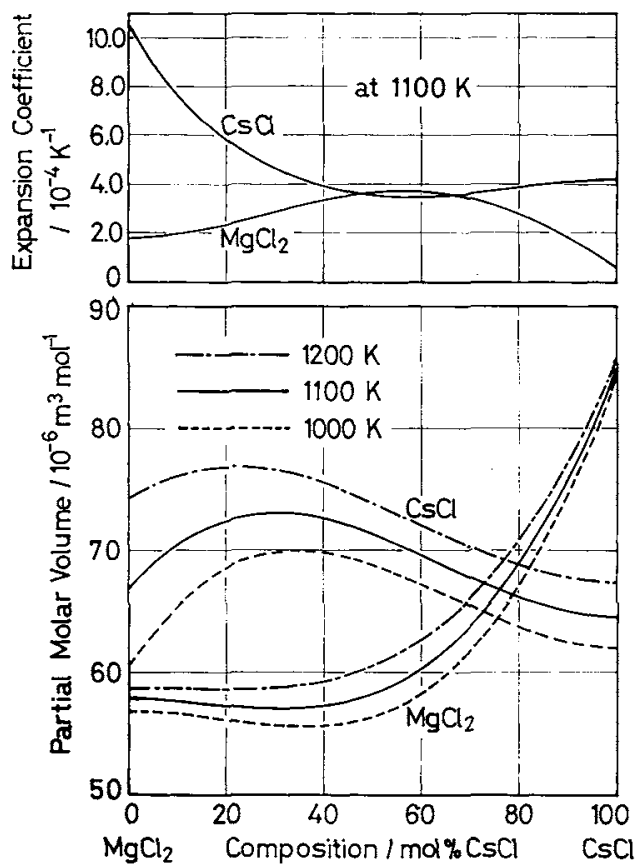

Fig.5 Partial molar volumes and their expansion coefficients of $\mathrm{MgCl}_{2}$ and $\mathrm{CsCl}$ in $\mathrm{MgCl}_{2}$-CsCl binary melt.

約 $50 \mathrm{~mol} \%$ 付近の組成から增加乙始め, $\mathrm{CsCl}$ 添加量の 增加之共に急激に增大する。一方 $\mathrm{CsCl}$ の部分モ几体積は $\mathrm{MgCl}_{2}$ の添加によって最初はゆるやが增加するが $\mathrm{CsCl}$ 20 30 mol\%の組成で最大値を示した後減少する. 部分モル 体積の膨張俰数は $\mathrm{CsCl} 60 \mathrm{~mol} \%$ 付近の組成で $\mathrm{MgCl}_{2} に$ ついては最大值, $\operatorname{CsCl}$ とついては最小值を示す。この組成 はFig.3の過鄱モ几体皘が最大となる組成にほぼ対応する。

以上の上うな本 2 成分系の体積的挙動は融体内ての錯化 合物の生成に関連していると考党られる。状態図(11) 炕よれ

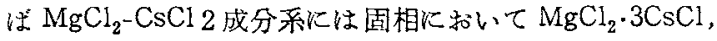
$\mathrm{MgCl}_{2} \cdot 2 \mathrm{CsCl}, \mathrm{MgCl}_{2} \cdot \mathrm{CsCl}$ 括び $3 \mathrm{MgCl}_{2} \cdot \mathrm{CsCl}$ なる中 間化合物が存在する。しかしながら $\mathrm{MgCl}_{2}$-アルカリ金属 塩化物の融体中に和いては一部に $\mathrm{MgCl}_{3}$ ななる錯イオンの 存在が認められてはいる(12)が，最近のラマンスペクトル の測定 ${ }^{(13)}$ や液相線よりの化合物解離種の検討 ${ }^{(14)}$ 节るいは 電気化学的測定 ${ }^{(15)}$ などとよると $\mathrm{MgCl}_{4}{ }^{2-}$ の存在のみが認 められると報告されている。融体中に $\mathrm{MgCl}_{4}{ }^{2-}$ なる錯イオ ソが存在することは $\mathrm{MgCl}_{2}: \mathrm{CsCl}=1: 2$ なる化学量論組 成付近に鋭い発熱のピークを認めたKleppa と McCarty ${ }^{(16)}$ の搌合熱測定結果からも理解さ礼る。 Pelton と Thompson ${ }^{(17)}$ は $\mathrm{MgCl}_{2}$ が溶融状態においてそれ自身の解離ある いはアルカリ金属塩化物など $\mathrm{Cl}^{-}$供与体の添加によって式 (3)のようK $\mathrm{MgCl}_{4}{ }^{2-}$ 錯イオンを生成するとしたモデル を用い，構成イオン種の变化について検討している。

$$
\left.\begin{array}{l}
\mathrm{MgCl}_{2}=\mathrm{Mg}^{2+}+2 \mathrm{Cl}^{-} \\
\mathrm{Mg}^{2+}+4 \mathrm{Cl}^{-}=\mathrm{MgCl}_{4}^{2-}
\end{array}\right\}
$$

このモデルによると $1100 \mathrm{~K}$ では純 $\mathrm{MgCl}_{2}$ の場合, 全 $\mathrm{Mg}$ 量の $37 \%$ が $\mathrm{Mg}^{2+}, 63 \%$ が $\mathrm{MgCl}_{4}{ }^{2-}$ として存在すること になるが， $\mathrm{MgCl}_{2}$ に CsCl を添加すると $\mathrm{MgCl}_{4}{ }^{2-}$ の安定
性が增すので $\mathrm{Cs}_{2} \mathrm{MgCl}_{4}$ なる化学量論組成では全 $\mathrm{Mg}$ 量の 95\%，さらに CsCl の多い組成ではほほ なる鉷イオンとして存在することになる。ただしアニオン 中の $\mathrm{MgCl}_{4}{ }^{2-}$ の分率が最大となる組成はCsCl $63 \sim 65 \mathrm{~mol} \%$ で西って化学量論組成とは一致せず，むしろ過剩モル体積 が最大るるいは部分モル体積の膨張係数が最大・最小を示 す組成とよく対応する。. $\mathrm{MgCl}_{4}{ }^{2-}$ の安定性は温度上昇と共 に低下するがその度合は比較的小さいので構成イオン種の 温度に上る存在比率の变化は体積的挙動の定性的な検討に おいては重要でないと考觉られる。

これらのことを考光併せると過剩モル体積が正になるの は $\mathrm{MgCl}_{4}{ }^{2-}$ の生成によるすのであり $\mathrm{MgCl}_{4}{ }^{2-}$ をアニオン とする化合物 $\left(\mathrm{Cs}_{2} \mathrm{MgCl}_{4}\right.$ および $\left.\mathrm{Mg} \cdot \mathrm{MgCl}_{4}\right)$ のル体積は かなり大きなるのであることがわかる。また膨張保数の組 成依存性が大きな变化を示す理由については次のよらに考 えられる。液体の膨張保数は一般には粒子間の相互作用が 強いほど小さい，純 $\mathrm{MgCl}_{2}$ の場合には電荷密度の大なる $\mathrm{Mg}^{2+}$ イオンが多量に存在するのでイオン間の相互作用が 強く膨張係数は小さいが $\mathrm{CsCl}$ 添加によって $\mathrm{Mg}^{2+}$ 少電荷 密度の小さい $\mathrm{MgCl}_{4}{ }^{2-}$ K変化し，からカチオン中の $\mathrm{Mg}^{2+}$ が $\mathrm{Cs}^{+}$によって置換されるようになるので膨張係数の急

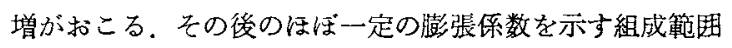
は $\mathrm{Cs}_{2} \mathrm{MgCl}_{4}$ あるいは $\mathrm{Mg} \cdot \mathrm{MgCl}_{4}$ なる化合物が主要な成 分となる組成であり，これらが比較的大きな膨張俰数を有 すると考えると良く説明でさる．CsCl $70 \mathrm{~mol} \%$ 以上の組

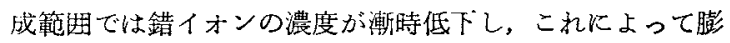
張係数の值は $\mathrm{CsCl}$ 本来の值に近つくくため增加の㑯向を示 すと考学られる。机過剩モル体積の温度による变化が $\mathrm{MgCl}_{2}$ の多小組成で大であるのは $\mathrm{MgCl}_{2}$ の膨張係数が小 さく $\mathrm{CsCl}$ の添加によって膨張保数の急增が起こるため, $\mathrm{CsCl}$ の多い組成に比へて䋧粋塩の膨張 保数との差が大と なるためであると考党られる。

部分モル体積の挙動が, $\mathrm{CsCl}$ 約 $50 \mathrm{~mol} \%$ 以下の組

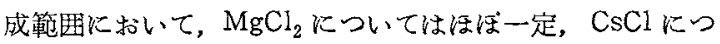
いては純紝塩よりかなり大きな值を示す理由は次のように 教えられる. 部分モル体積はその組成に打ける成分の存在 形態に関連するすのであるから上述のイオン種の变化をと りあげてみる、 $\mathrm{MgCl}_{2}$ を含导融体中では $\mathrm{Mg}$ は $\mathrm{Mg}^{2+}$ あ るいは $\mathrm{MgCl}_{4}{ }^{2-}$ として存在するのでこの比は $\mathrm{MgCl}_{2}$ の存 在形態を特徽つけているるのとみなすことができる。純 $\mathrm{MgCl}_{2}$ ては $\mathrm{Mg}^{2+}: \mathrm{MgCl}_{4}{ }^{2-}$ の比は約 1.7 である。これに $\mathrm{CsCl}$ を涯加すると $\mathrm{Mg}^{2+}$ の減少括よび $\mathrm{MgCl}_{4}^{2-}$ の增加が 起こるのでこの $\mathrm{MgCl}_{4}{ }^{2-}$ のうちCs+のモル数の $1 / 2$ すなわ ち $\mathrm{Cs}_{2} \mathrm{MgCl}_{4}$ を形成していると考穴られる分を除いて，先 に挙壮た比を求めてみるとこの值は $\mathrm{CsCl}$ の添加に伴い最 初幾分減少した後,徐々に增加するが $\mathrm{CsC1} 60 \mathrm{~mol} \%$ 程度ま での組成範围に和いては 1.4〜2.0とほぼー定である。す なわちこの組成範围ては $\mathrm{MgCl}_{2}$ の存在形態は純粋塩の場 合とほぼ同様で趽るため部分モル体積に大きな変化が現れ 
ず，逆炕 $\mathrm{CsCl}$ は大部分が $\mathrm{Cs}_{2} \mathrm{MgCl}_{4}$ として存在するために 大きな部分モル体積を示す百のと考光られる。一方 CsCl の多い組成範围では $\mathrm{MgCl}_{2}$ の大部分が $\mathrm{Cs}_{2} \mathrm{MgCl}_{4}$ となる ため $\mathrm{MgCl}_{2}$ の部分モル体積は大きな增加を示し， CsCl は 生成した $\mathrm{Cs}_{2} \mathrm{MgCl}_{4}$ によって单に希釉された形になるのて 純 $\mathrm{CsCl}$ のそれに近い部分モル体積を示すようになるるの と考兄られる。

このよ5に本 2 成分系の体積挙動は $\mathrm{MgCl}_{4}^{2-}$ なる錯イ オンを有する化合物生成に密接に関連していることが明 らかになったのでこれらの化合物の体積について定量的に 検討してみる。このために以下の条件が満足されるものと 仮定する。

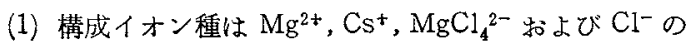
4 種類のみである.

（2）各イオン種のモル体積は組成にかかからず一定であ りかつそれらの間には加成性が成立する。

上記の上5に仮定すると式(4)が導かれる。

$$
\begin{aligned}
& V_{M}=n_{\mathrm{Mg}^{2}} V_{\mathrm{Mg}^{2+}}+n_{\mathrm{Cs}^{2}}{ }^{2} V_{\mathrm{Cs}^{2+}}
\end{aligned}
$$

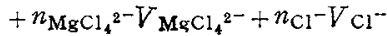

ここで $V_{M}$ は Table 1 に示した密度より式(1)を用いて 求めたモル体積, $n$ は $\mathrm{MgCl}_{2}-\mathrm{CsCl} 2$ 成分采の 1 モル中に 含まれる各イオン種のモル数であり Peiton のモデルを用 いて著者らが算出した值，Vは各イオン種のモル体積であ る。この場合, 電気的中性を保持するために式(5)が満足 されねばならない。

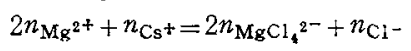

式(4)に式(5)を代入すると式(6)の4 通りの表現が得ら れる.

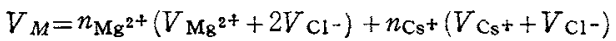

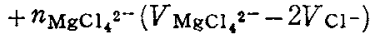

$$
\begin{aligned}
& V_{M}=n_{\mathrm{Mg}^{2}}+\left(V_{\mathrm{Mg}^{2+}}+\mathrm{V}_{\mathrm{MgCl}_{4}{ }^{2-}}\right) \\
& +\frac{1}{2} n_{\mathrm{Cs}^{+}}\left(2 V_{\mathrm{Cs}^{+}}+V_{\left.\mathrm{MgCl}_{4}{ }^{-}\right)}\right)
\end{aligned}
$$

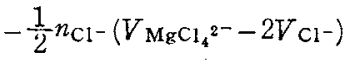

$$
\begin{aligned}
& V_{M}=-n_{\mathrm{Mg}^{2}}\left(2 V_{\mathrm{Cs}^{+}}-V_{\mathrm{Mg}^{2+}}\right)
\end{aligned}
$$

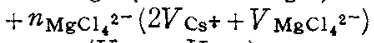

$$
\begin{aligned}
& +n_{\mathrm{Cl}}-\left(V_{\mathrm{Cs}}++V_{\mathrm{Cl}}-\right) \\
& V_{M}=\frac{1}{2} n_{\mathrm{Cs}^{*}}\left(2 V_{\mathrm{Cs}}+-V_{\mathrm{Mg}^{2+}}\right)
\end{aligned}
$$

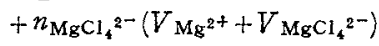

$$
\begin{aligned}
& +\frac{1}{2} n_{\mathrm{Cl}^{-}}\left(V_{\mathrm{Mg}^{2+}}+2 \mathrm{VCl}^{-}\right)
\end{aligned}
$$

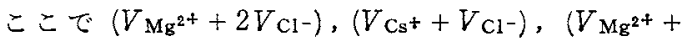

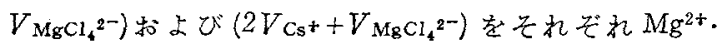
$2 \mathrm{Cl}^{-}, \mathrm{Cs}^{+} \cdot \mathrm{Cl}^{-}, \mathrm{Mg}^{2+} \cdot \mathrm{MgCl}_{4}{ }^{2-}$ 特よび $2 \mathrm{Cs}^{+} \cdot \mathrm{MgCl}_{4}{ }^{2-}$ なる イオン対†のモル体積とみなせば,これらの値は式（6)を 用い最小自乗法化よって決定することができる。このよう

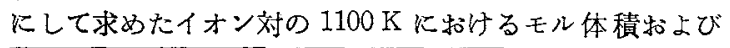

†これまではこれら老 $\mathrm{Cs}_{2} \mathrm{MgCl}_{4}$ などの化合物として 考えてきたが，ここで示したモデルにおいてはカチ オン拉よびフニオンはそれぞれ2種類ずつであり， イオンの分率は求委るが，化合物としての分率を求 めることはできないため，イオンの組合せとして表 わすことにした。
Table 3 Molar volume and expansion coefficient of each ion pair at $1100 \mathrm{~K}$.

\begin{tabular}{c|c|c}
\hline Ion pair & $\mathrm{V} / 10^{-6} \mathrm{~m}^{3} \mathrm{~mol}^{-1}$ & $\alpha / 10^{-4} T^{-1}$ \\
\hline $\mathrm{Mg}^{2+} .2 \mathrm{Cl} 1^{-}$ & 48.8 & 1.22 \\
$\mathrm{Cs}^{+} \cdot \mathrm{Cl}^{-}$ & 65.2 & 3.89 \\
$\mathrm{Mg}^{2+} \cdot \mathrm{MgCl}^{4-}$ & 119.7 & 2.75 \\
$2 \mathrm{Cs}^{+} \cdot \mathrm{MgCl}^{4^{-}}$ & 201.3 & 3.86 \\
\hline
\end{tabular}

膨張係数を Table 3 に示した。結果はFig.3〜5 から定性 的に予想されたように $2 \mathrm{Cs}^{+} \cdot \mathrm{MgCl}_{4}{ }^{2-}$ のモル体積は $\mathrm{Cs}^{+}$. C1-の 2 倍および $\mathrm{Mg}^{2+}$.2Cl-のモル体積の和よりもかな り大である注か, $\mathrm{Mg}^{2+} \cdot \mathrm{MgCl}_{4}{ }^{2-}$ のモル体積す $\mathrm{Mg}^{2+} \cdot 2 \mathrm{Cl}$ のモル体積の 2 倍より大きく，同じ化学組成を有していて

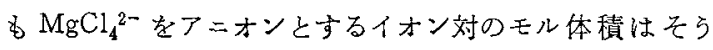
でないるののモル体嫧よりかなり大きなるので方ることが わかる。杰た膨張保数についても $\mathrm{Mg}^{2+} \cdot 2 \mathrm{Cl}^{2}$ なるイオン 対のそれが他のイオン対に比べて極端に小さいことが明ら かになった。すなうち $\mathrm{MgCl}_{2}$ の膨張係数が小さいのは $\mathrm{Mg}^{2+} \cdot 2 \mathrm{Cl}$-なるイオン対が多量に存在するためでありこ れに $\mathrm{CsCl}$ を添加すれば $\mathrm{Mg}^{2+} \cdot 2 \mathrm{Cl}^{-}$イオン対の数が減少す るため膨張係数の急激な增加が起こるものと考えられる。

ここで挙げたモデルは $\mathrm{MgCl}_{2}$ を含む溶融 2 成分系の構 成イオン種を 4 種類のみとした最も単純なむのであるが， これを用いることにより本 2 成分系の体積挙動をかなり定 量的に説明することが可能となった。

\section{V. 結言}

溶融 $\mathrm{MgCl}_{2}-\mathrm{CsCl} 2$ 成分系の密度を液相線 $1200 \mathrm{~K}$ の 温度笔团にわたってマノメータ法を用いて測定を行い，モ ル体積，膨張保数および部分モル体積を求めて検討を加え た. 得られた結果は次のように要約さ礼る。

本 2 成分系の密度は $\mathrm{CsCl}$ の堌加仁伴って増大するが， 膨張保数は純 $\mathrm{MgCl}_{2}$ に特いて最小であり CsCl の添加之 共に CsCl $30 \mathrm{~mol} \%$ 付近の組成まで急増した後ほ汸一定の 値をとるようになる。モル体積は全組成範围で加成性より 正作倚し，その扁倚量は CsC1 約 $65 \mathrm{~mol} \%$ の組成で最 大となる、 $\mathrm{MgCl}_{2}$ の部分モル体積は $\mathrm{CsCl} 50 \mathrm{~mol} \%$ 以上 の組成で $\mathrm{CsCl}$ の增加之共に急激偪大し， $\mathrm{CsCl}$ の部分 モル体積は CsCl 20 40 mol\% の組成で最大となる。

これらの挙動は $\mathrm{Mg}^{2+}, \mathrm{Cs}^{+}, \mathrm{MgCl}_{4}{ }^{2-}$ 和よび $\mathrm{Cl}^{-}$を構成 イオン種とするモデルを用い，イオン種の組成による変化 や電荷密度の違いなどより良く説明されまたこのモデル に基づいて融体中に和ける錯化合物心体積举動を定量的に 表わすことができた。

\section{文南}

(1) K. Grjotheim, J.L. Holm, B. Lillebuen and H.A.фye : Trans. Faraday Soc., $67(1971), 640$.

（2）江島辰彦，小笠原正俊:日本金属学会誌，39(1975), 293.

(3) K.Grjotheim, R.Nikolic and H.A. $\phi$ ye : Acta Chem. Scand., $24(1970), 489$. 
（4）江島辰彦，中村英次：日本金属学会誌，39(1975), 680 .

（5）江島辰彦, 岩崎和春, 斎藤元治：日本金属学会誌, $41(1977), 784$.

（6）佐藤 僙, 小林賢一, 江島唇彦：日本金属学会誌, $43(1979), 97$.

(7) J.N.Reding: J.Chem. End. Data, 10 (1965) , 1.

(8) P.W.Huber, E.V.Potter and H.W.St.Clair: U.S.Bur.Mines Rep., 4858(1952), 1.

(9) I.S.Yaffe and E.R.van Artsdalen: J.Phys. Chem., $60(1956), 1125$.

(10) H.Schinke and F. Sauerwald : Z.anorg.allgen. Chem., 287 (1956), 313.

(11) E.M.Evin, C.R.Robbins and H.F.McMurdie, ed. : Phase Diagrams for Ceramists, 2nd ed., The American Ceramic Society, USA, (1965).
(12) K.Balasubrahmanyam: J.Chem. Phys., 44 (1966) , 3270 .

(13) V.A.Maroi, E.J.Hathaway and E.J.Cairns: J.Phys. Chem., 75(1971), 155.

(14) H.Flood and S.Urnes : Z.Elektrochem., 59 (1955), 834 .

(15) H.Ikeuchi and C.Krohn : Acta Chem. Scand., $23(1969), 2230$.

D.E.Neil, H.M. Clark and R.H. Wiswall, Jr. : J.Chem. Eng. Data, 10(1965), 21.

(16) O.J.Kleppa and F.G.McCarty : J.Phys.Chem., $70(1966), 1249$.

(17) A.D.Pelton and W.T. Thompson : Can.J. Chem., 48(1970), 1585.

\title{
$\mathrm{Al}-8 \% \mathrm{Mg}$ 合金の水素脆性と応力腐食割れに 及ぼす加工熱処理の影響
}

\author{
大西忠一* 東 健 司** 中谷義三*
}

J.Japan Inst. Metals, Vol.45, No.4(1981),pp.373 378

Effect of Thermomechanical Treatment on Hydrogen Embrittlement and Stress Corrosion Cracking of $\mathrm{Al}-8 \% \mathrm{Mg}$ Alloy

Tadakazu Ohnishi*, Kenji Higashi** and Yoshizo Nakatani*

In the conventional aging of $\mathrm{Al}-8 \% \mathrm{Mg}$ alloy, the hydrogen embrittlement and the decrease of stress corrosion cracking life by hydrogen permeation are markedly produced in the hardening region of aging process. The step aging hardly alters these behaviors, because this treatment brings about an insignificant change in the microstructure. The thermomechanical treatment effectively depresses the embrittlement and the decrease of life by hydrogen permeation over the whole range of testing conditions used in this study. This effect seems to be attributable to a depression of precipitation in the grain boundary at the final aging and to an introduction of the dislocation structure by the intermediate deformation. The effect of dislocation structure and the role of dislocation movement in the hydrogen transport to the critical region of cracking are discussed.

(Received September 16, 1980)

\section{I. 緒言}

$\mathrm{A} 1-\mathrm{Mg}$ 系合金は構造用材料として広く実用に供されて いるが，高マグネシウム合金では応力腐食割れ感受性の高 、欠点を有する。その改善法の一つとしてT7 処理のよら なミクロ組織の粗大化を利用する方法があるが，これは材 料強度の㬢牲を免れ兑ない。この点で勒性の低下を伴えず 強度の增加を図りうる加工熱处理法(以下 TMT) は注目さ
れる技術であり，㐫力腐食割れの防止にも有効であるとさ れている(1)(2). 筆者らは $\mathrm{A} 1-8 \% \mathrm{Mg}$ 合金の強さと応力腐 食割れに対するTMT の効果を検討し，析出組織の微細化 と転位の存在が粒界の脆化機構に影響し有効な作用をする と考察した ${ }^{(3)}$ 。一方応力腐食割れ《関する筆者らの研究に よれば，水素に上る局部的伦化がその発生機構と密接に関 連していると考光られ(4)〜(8)，この観点からすれば，TMT により導入された転位は水素をトラップすることで脆化に

* 大阪府立大学工学部 (College of Engineering, University of Osaka Prefecture, Sakai)

**大阪府立大学大学院 (Graduate School, University of Osaka Prefecture, Sakai) 